\title{
Peculiarities of Sexual Dimorphism in Patients with cancer of Prostate
}

\author{
N Yu Klimov* and AV Andreychikov \\ Department of Urology, Andrology and Sexology, Krasnoyarsk State Medical University, Russia
}

Received: 阱 August 10, 2018; Published: 眥 August 24, 2018

*Corresponding author: SNikolay Yu Klimov, Department of Urology, Andrology and Sexology, Krasnoyarsk State Medical University,KGBU “Krasnoyarsk Regional Clinical Oncology Clinic named after AI. Kryzhanovsky, Russia

\begin{abstract}
One of the most common oncological diseases in men is prostate cancer (PC). According to the frequency of occurrence among the causes of cancer death in men, it ranks second to bronchogenic lung carcinoma [1]. During the last 30 years, the incidence of prostate cancer increased significantly worldwide. Moreover, a change of the existing paradigm takes place at the present moment, according to which prostate cancer is highly androgen-dependent disease [2].
\end{abstract}

Objective: To establish the most common somatotype of patients with prostate cancer (PC) according to the index of Tanner and Rees-Eysenck body index.

Tasks:

a. To carry out anthropometry;

b. To compare the incidence of somatotype identified by Tanner and Rees-Eysenck indices in the group of patients with PC and healthy men of the same age;

c. To determine the Quetelet index in patients with prostate cancer and healthy men.

\section{Introduction}

42 patients with morphologically confirmed diagnosis of prostate cancer were examined in the urology departments of Krasnoyarsk hospitals. Age of the patients - 46-91 years (middle age $69,3 \pm 2,6$ ). Standard anthropometry was made for all of them in 27 parameters [3-5] with the calculation of osteometric indices of Rees-Eysenck [3-4] and Tanner according to the known formulas $[3,4,6]$. Anthropometric data taken from the healthy men of the same age were used as a comparison group [5]. Statistical data management was made using the Student's test and $\chi 2$. Differences were considered significant by criteria t (Student's test) and $\chi 2$ at $\mathrm{p}<0.05[7,8]$.

\section{Results}

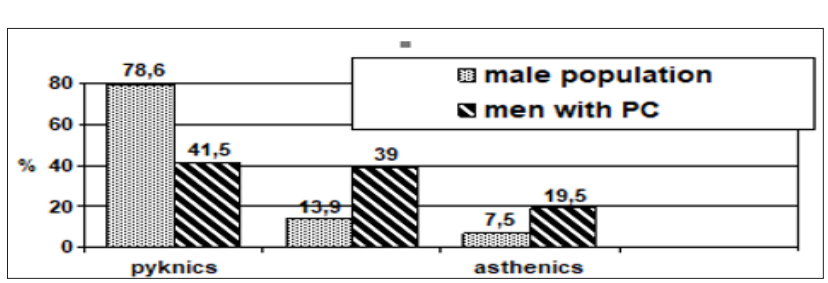

Figure 1: Comparison of the incidence of somatotypes according to the Rees-Eysenck index among patients with prostate cancer and male population.
Determination of patient somatotype by Rees-Eysenck index showed that men of pyknic type suffering from PC made up $41.5 \%$, normosthenic type $-39 \%$, asthenic type - $19.5 \%$. When comparing the frequency of patient somatotypes and men of the population there is a significant difference. These comparisons are shown on (Figure 1). By distributing the patients into the somatotypes by index of Tanner - the index of sexual dimorphism - it was found out that gynaecomorphic males amount $65.6 \%$, mesomorphic ones - 31.8\% and andromorphic group made up 2.6\%. Compared with the population norms - a striking contrast. Among the patients gynaecomorphic males prevail and andromorphic males are virtually absent (Figure 2).

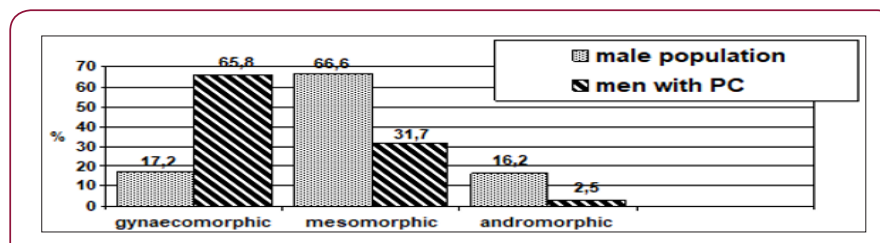

Figure 2: Comparison of the incidence of somatotypes according to the Tanner body index among patients with prostate cancer and male population.

According to the foreign literature patients with $\mathrm{PC}$, in comparison with male population are obese (Fontana S.L, et al., 
2009; Moorthy K. et al. 2008). In our opinion, in recent times a wide spread attempt to explain that carcinogenesis is caused by food conditions in respect of prostate cancer is untenable because while comparing body mass index (BMI) of patients with prostate cancer we obtained the following results: patients with PC have BMI = $26,51 \pm 0,62$. When compared with the population data $(\mathrm{BMI}=$ $25,6 \pm 0,23 ; \mathrm{P}>0.05$ ) there are no differences! Conclusion: patients with pathology of the prostate and men population are equally overweight.

\section{Conclusion}

a. Among patients with prostate cancer gynaecomorphic and mesomorphic males are found predominantly but gynaecomorphic somatotype is the most frequently occurring. Mesomorphic type dominates among male population. Consequently, estrogens / androgens ratio is of direct relevance to the etiology of prostate cancer.

b. According to our findings: the more developed male characteristics (masculinity), the less prostate cancer probability.

c. According to the body mass index, patients with PC do not differ from the male population, and therefore, excess food and obesity have no relation to prostate cancer.

\section{References}

1. Lopatkina AN (2009) Urologiya: natsionalnoe rukovodstvo [Urology: national leadership]. Moscow, GEOTAR_Medif p. 1024.

ISSN: 2574-1241

DOI: 10.26717/BJSTR.2018.08.001637

Nikolay Yu Klimov. Biomed J Sci \& Tech Res

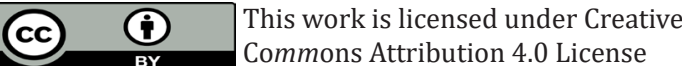

Submission Link: https://biomedres.us/submit-manuscript.php
2. Huggins C, Stevens RE, Hodges CV (1941) Studies on prostatic cancer II: The effect of castration on advanced carcinoma of prostate gland. Arch Surg 43: 209-223.

3. Nikolaev VG, Nikolaeva NN, Sindeeva LV, Nikolaeva LV (2007) Antropologicheskoe obsledovanie v klinicheskoy praktike [Anthropological examination in clinical practice]. Krasnoyarsk, LLC Verso p. 173.

4. Lukyanova IE, Ovcharenko VA (2008) Antropologiya [Anthropology] Moscow: INFA publ p. 240.

5. Nikolaev VG, Sindeeva LV (2010) Opyt izucheniya formirovaniya morfofunktsional'nogo statusa naseleniya Vostochnoy Sibiri [The experience of studying the formation of the morphofunctional status of the population of Eastern Siberia]. Saratov Journal of Medical Sciences 6(2): 238-241.

6. Nikolaev VG, Sharaykina EP, Sindeeva VP, Efremova VA (2005) Metody otsenki individual'no-tipologicheskikh osobennostey fizicheskogo razvitiya cheloveka [Evaluation methods of individual and typological features of human physical development]: learning aids, Krasnoyarsk, KrasGMA: p. 111.

7. Sindeeva LV (2001) Harakteristika parametrov fizicheskogo razvitiya muzhskogo naseleniya starshih vozrastnyih grupp [Characteristics of physical development parameters of the male population in older age groups]. Synopsis of the thesis, Krasnoyarsk p. 28.

8. Tanner D (1968) Rost i konstitutsiya cheloveka [Growth and constitution of the person]: trans. from English. / Harrison D, Uayner D, Tanner D, Barnikot N Human Biology. Moscow, pp. 247-326.

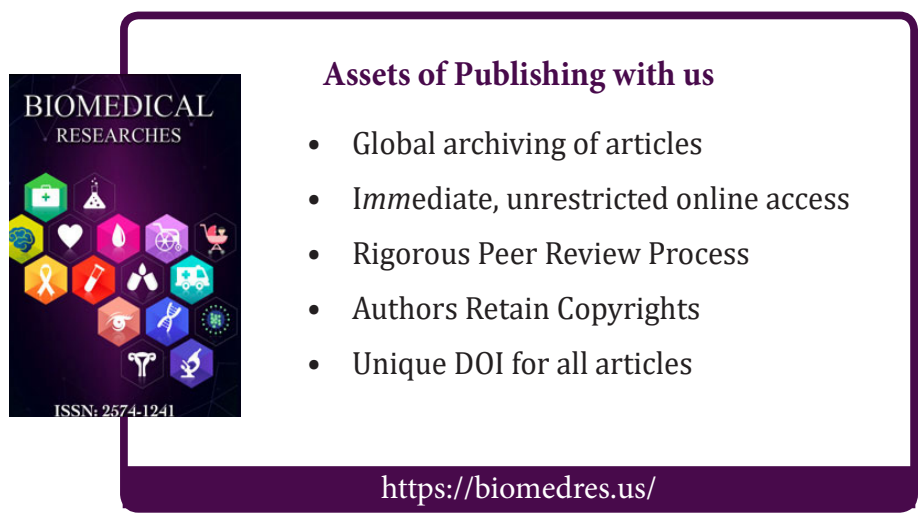

